\title{
Benthic metabolism in shallow coastal ecosystems of the Banc d'Arguin, Mauritania
}

\author{
Jacques Clavier ${ }^{1, *}$, Laurent Chauvaud ${ }^{1}$, Erwan Amice ${ }^{1}$, Pascal Lazure ${ }^{2}$, \\ Matthijs van der Geest ${ }^{3}$, Pierre Labrosse ${ }^{4}$, Ahmed Diagne ${ }^{4}$, Antoine Carlier ${ }^{5}$, \\ Sylvain Chauvaud ${ }^{6}$
}

\begin{abstract}
${ }^{1}$ IUEM, Laboratoire des Sciences de l'Environnement Marin, UMR CNRS 6539, Institut Universitaire Européen de la Mer, Technopôle Brest-Iroise, Place Nicolas Copernic, 29280 Plouzané, France

${ }^{2}$ IFREMER, Laboratoire de Physique Hydrodynamique et Sédimentaire, Centre de Bretagne, ZI de la pointe du Diable, CS 10070, 29280 Plouzané, France

${ }^{3}$ NIOZ, Royal Netherlands Institute for Sea Research, Department of Marine Ecology, PO Box 59, 1790 AB, Den Burg, Texel, The Netherlands

${ }^{4}$ Institut Mauretanien de Recherches Océanographiques et des Pêches (IMROP), BP 22, Nouadhibou, Mauritania

${ }^{5}$ IFREMER, Laboratoire d'Écologie Benthique, Centre de Bretagne, ZI de la pointe du Diable, CS 10070, 29280 Plouzané, France ${ }^{6}$ Télédétection et Biologie Marine (TBM), 6 rue Castel, 56400 Auray, France
\end{abstract}

\begin{abstract}
Benthic primary production and respiration were investigated at 4 sites representative of the major coastal communities bordering the Sahara Desert in the Banc d'Arguin, Mauritania, Western Africa. These sites correspond to intertidal Zostera noltii beds $\left(270 \mathrm{~km}^{2}\right)$, intertidal bare sediments $\left(88 \mathrm{~km}^{2}\right)$, subtidal Cymodocea nodosa beds $\left(374 \mathrm{~km}^{2}\right)$, and subtidal bare sediments $\left(311 \mathrm{~km}^{2}\right)$. At each site, production-irradiance relationships were established in situ in November 2008 and January 2010, and used to calculate daily carbon fluxes for these communities. In intertidal areas, compared to emersion, the gross maximal photosynthetic rates for $Z$. noltii bed and bare sediment communities were on average 8- and 7 -fold higher during immersion, respectively; community respiration rates were 3 - and 18 -fold higher during immersion, respectively. The $Z$. noltii bed was autotrophic during the 2 study periods, with a mean ( $\pm 95 \%$ probability limit) daily net community production of $71.3 \pm 58.6 \mathrm{mmol} \mathrm{C} \mathrm{m} \mathrm{C} \mathrm{d}^{-1}$. Conversely, net community production was always negative in intertidal regions and subtidal bare sediments (average $-7.3 \pm$ $46.7 \mathrm{mmol} \mathrm{C} \mathrm{m} \mathrm{d}^{-1}$ and $-47.0 \pm 38.9 \mathrm{mmol} \mathrm{C} \mathrm{m}^{-2} \mathrm{~d}^{-1}$, respectively); the $C$. nodosa bed was negative in November $\left(-96.2 \pm 85.1 \mathrm{mmol} \mathrm{C} \mathrm{m}^{-2} \mathrm{~d}^{-1}\right)$ and positive in January (33.4 $\pm 82.6 \mathrm{mmol}$ $\mathrm{C} \mathrm{m}^{-2} \mathrm{~d}^{-1}$ ). Community respiration was highest in subtidal communities, indicating active mineralization of organic matter and demonstrating that $Z$. noltii beds are likely to increase the biological richness of the Banc d'Arguin by exporting energy. Our results confirm the ecological importance of seagrass beds in the net coastal carbon fluxes and justify their protection.
\end{abstract}

KEY WORDS: Seagrass - Carbon metabolism - Intertidal - Subtidal · Respiration · Primary production $\cdot$ Western Africa

Resale or republication not permitted without written consent of the publisher

\section{INTRODUCTION}

Coastal areas are among the most productive marine ecosystems in the world (Solan et al. 2004, Waycott et al. 2009, Bierman et al. 2011), and play a major, and economically significant, role in marine fisheries by providing nursery and feeding grounds (Worm et al. 2006, Martínez et al. 2007). Near-shore marine ecosystems are subject to various environmental conditions (Cloern \& Jassby 2008) that lead to 
a mosaic of habitats, which has been reported to enhance biodiversity (Matias et al. 2010). However, they are also vulnerable to human-induced disturbances that, conversely, contribute to the loss of marine biodiversity; these ecosystems would benefit from conservation measures (Jackson 2008), such as establishing protected areas. One of the goals for marine protected areas is the conservation of commercially valuable or socially important species, like fishes and birds (Robinson 2011), that often depend on the amount of organic matter present in the ecosystem. A reasonable estimate of the production of major communities and an analysis of control factors are, therefore, required for determining the ecological condition of coastal zones and marine protected areas (Jones 2001).

The Banc d'Arguin is a coastal ecosystem located in Mauritania, on the Atlantic coast of Africa (see Fig. 1). In this region bordering the Sahara Desert, rainfall is very low and there is no estuary. The total area of the Banc d'Arguin National Park, created in 1976, is $12000 \mathrm{~km}^{2}$, with approximately equal contributions from terrestrial and marine environments. The latter is characterized by extensive intertidal and shallow-water zones that are mostly covered with seagrass beds (Wolff \& Smit 1990), which are particularly widespread in the vicinity of Tidra Island (see Fig. 1). The high biological productivity in the coastal waters of this national park is consistent with the presence of more than 2 million migratory and nesting shorebirds (Wolff \& Smit 1990, Wolff et al. 1993a, Wolff \& Michaelis 2008), and with its role as a nursery for numerous marine species, including fishery resources (Jager 1993, Schaffmeister et al. 2006).

In the intertidal and shallow-water ecosystems of the Banc d'Arguin, global phytoplanktonic biomass and production are considered to be lower than those of the upwelling zone (Sevrin-Reyssac 1993), even though recent remote-sensing data suggest more eutrophic conditions (Michel et al. 2011). Therefore, benthic communities are likely the major contributors to organic carbon fluxes (Wolff et al. 1993b). The production of benthic communities has already been investigated in this area (De Jong et al. 1991, van Lent et al. 1991, Vermaat et al. 1993), and Hemminga \& Nieuwenhuize (1991) estimated that the export of organic material from intertidal seagrass beds is low, since most of senescent leaves are trapped in seagrass beds. Based largely on these data, a first comprehensive overview of the functioning of the Banc d'Arguin ecosystem was established by Wolff et al. (1993b). Twenty years after these studies, an approach encompassing the benthic productivity of vegetated and unvegetated areas, considering both intertidal and subtidal zones, is still needed to evaluate the energetic status of tidal flats and shallow inshore waters in the Banc d'Arguin National Park area. It is, thus, particularly important to determine whether net community production (NCP) is positive, indicating an autotrophic system that is likely to export energy to neighboring areas (Clavier \& Garrigue 1999, Geertz-Hansen et al. 2011).

To address these issues, we used in situ benthic chamber incubations to estimate NCP and to derive community respiration (CR) and gross community production (GCP) in the major intertidal and subtidal benthic communities of the Banc d'Arguin. The benthic chamber method has been extensively used in recent decades to study solute fluxes through the sediment-water interface in deep sea, continental shelf, and coastal environments (Viollier et al. 2003). More recently, measurements of gaseous exchanges at the soil-air interface in benthic chambers, which were originally developed on land (Parker et al. 2013), have been applied to the intertidal zone at the community scale (Migné et al. 2002). These techniques allow primary production and respiration rates to be estimated from direct or indirect measurements of carbon fluxes. However, few studies have attempted to estimate metabolic fluxes both during emersion and submersion of intertidal ecosystems (Alongi et al. 1999, Gribsholt \& Kristensen 2003, Cook et al. 2004, Silva et al. 2005, Ouisse et al. 2011, Faber et al. 2012); their results did not show a clear influence of emersion on benthic metabolism, although this knowledge is crucial for estimating the daily carbon production of benthic intertidal communities. In the present paper, we establish carbon production-irradiance curves during emersion and immersion at stations representative of the major intertidal benthic communities of the shallow parts of the Banc d'Arguin, to estimate the daily carbon budget during the studied periods. The results are compared to subtidal communities to assess the importance of the large intertidal seagrass beds and to contribute to understanding of the ecological functioning of the shallow areas of the Banc d'Arguin.

\section{MATERIALS AND METHODS}

\section{Study sites}

This study was conducted in the southern part of the Banc d'Arguin, Mauritania (Fig. 1) where the tidal range is $\sim 2.5 \mathrm{~m}$ during spring tides (Wijnsma et al. 


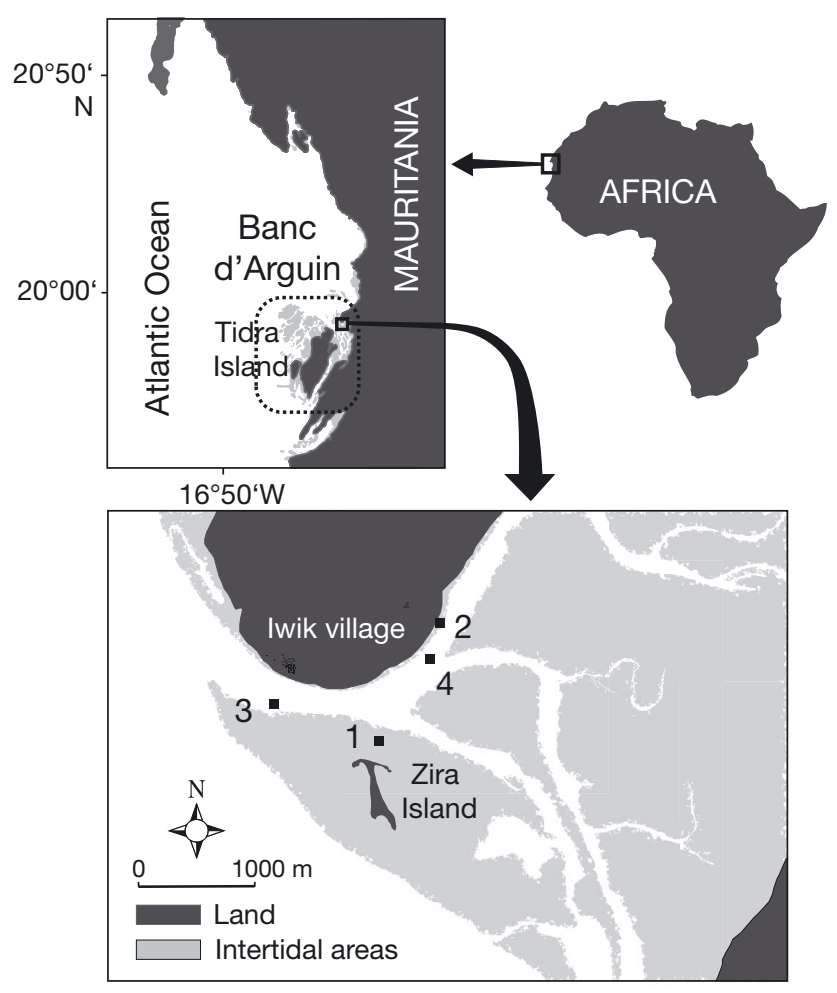

Fig. 1. Location of the 4 sampling sites in the Banc d'Arguin (Western Africa). 1: intertidal Zostera noltii bed; 2: intertidal bare sediment; 3: subtidal Cymodocea nodosa bed; 4: subtidal bare sediment

1999). We established the relative extent of benthic communities using remote sensing and extensive field validation. The area covered by the different benthic communities, from the intertidal zones to a depth of $\sim 5 \mathrm{~m}$, was estimated from the analysis of SPOT images taken in 2002. A series of 850 field surveys were performed to ground-truth the benthic assemblages. Over a total investigated area of $1114 \mathrm{~km}^{2}$, intertidal areas were dominated by Zostera noltii Hornem. beds interspersed with comparatively rare Halodule wrightii Aschers. beds (24\% of the total area), together with bare sediment (8\%) mainly composed of fine sand. Cymodocea nodosa (Ucria) Aschers. beds (34\%) and bare sediment (28\%) also dominated by fine sand made up the bulk of the subtidal benthic habitats. Miscellaneous benthic habitats, corresponding to subtidal algal beds, high-shore intertidal halophytes, and intertidal and subtidal muddy and rocky areas, were of minor relative importance (6\% of the total area). Supratidal hypersaline areas (sebkhas) were not considered in this study.

To estimate the benthic carbon production of these shallow coastal areas, we established NCP/irradiance $(P$ vs. $E$ ) relationships for the 4 major benthic communities listed above (1043 $\mathrm{km}^{2}$, comprising $94 \%$ of the investigated area). $P$ vs. $E$ curves were established near Iwik village (Fig. 1) on November 1-12, 2008 and January 21-31, 2010. NCP was assessed at 4 sites underwater, and during emersion of the 2 intertidal communities. Zostera noltii bed metabolism was studied near Zira Island, in a place where seagrass abundance is representative of most of the studied area (Clavier et al. 2011, Folmer et al. 2012). Intertidal bare-sediment NCP was measured on a site without macrophytes. Both intertidal stations were located around mid-tide level, in the middle of the $Z$. noltii distribution range. The depth of the subtidal Cymodocea nodosa bed studied near Zira Island was also in the middle of the species distribution range, and the site of the subtidal bare sediment survey was located in a channel.

\section{Field measurements}

$\mathrm{CO}_{2}$ fluxes during emersion and dissolved inorganic carbon (DIC) fluxes underwater were measured using benthic chambers covering $0.2 \mathrm{~m}^{2}$ (Fig. 2). Three replicate vinyl polychloride rings were inserted into the sediment at locations chosen to encompass the local variation in seagrass biomass, and randomly on bare-sand areas. Hemispheres were fixed tightly to the bases to trap a known volume of $\sim 501$, varying according to the depth of ring insertion into the substrate. To establish $P$ vs. $E$ relationships, clear chambers were used to assess NCP at various irradiance levels, including night conditions in emersion or under opaque domes in submersion. The experimental equipment was assembled by divers, even on intertidal sites during high tide, to minimize the effects of trampling the very soft substrate. Measurements at each sampling site were performed at the same location.

At intertidal sampling sites, $\mathrm{CO}_{2}$ measurements were carried out during emersion, after gently draining the bases of retained water to match the surrounding area. The domes were secured and the isolated volume of air was stirred for homogenization using a small battery-operated fan (Fig. 2A). $\mathrm{CO}_{2}$ concentration was measured in a closed circuit (Migné et al. 2002) connected to a calibrated infrared gas analyzer (Li-820, LI-COR) in which air circulation was forced at a rate of $\sim 1 \mathrm{~min}^{-1}$ by an adjustable pump (TD22N, Brailsford). A desiccation column filled with anhydrous calcium sulfate (Drierite) was placed at the gas entry into the analyzer. The $\mathrm{CO}_{2}$ concentration $\left(\mathrm{ppm}=\mu \mathrm{mol} \mathrm{CO}_{2} \mathrm{~mol}\right.$ air $\left.^{-1}\right)$ was dis- 

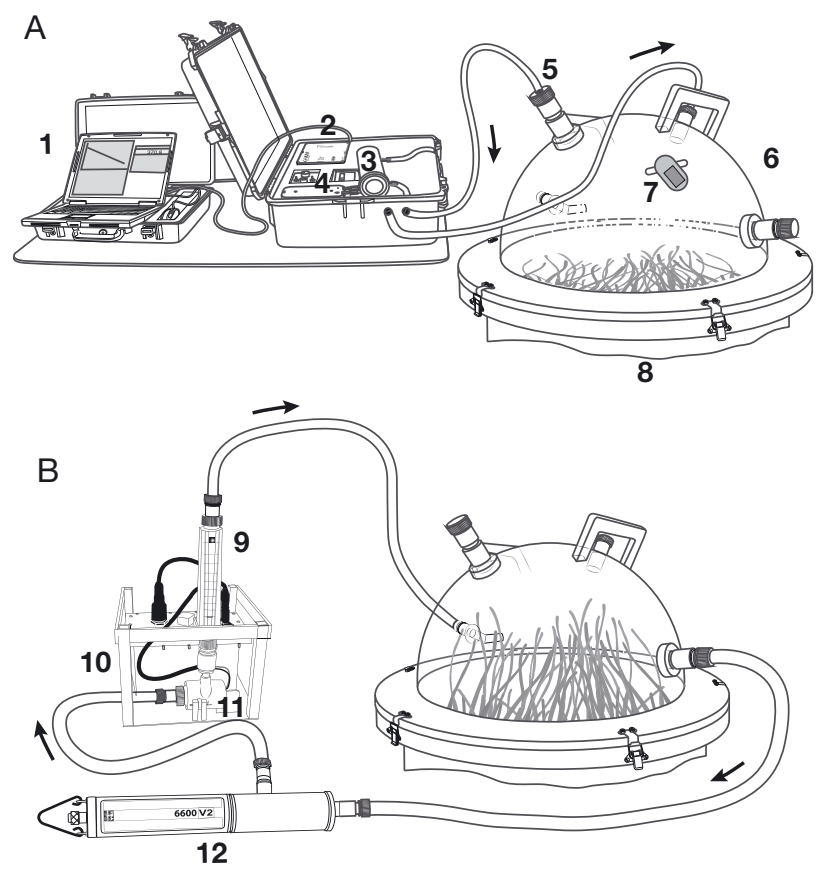

Fig. 2. Schematic representation of the apparatus used to measure benthic metabolism at the sediment-water interface during (A) emersion and (B) immersion. 1: laptop computer; 2 : infrared gas analyzer; 3 : desiccant; 4 : air pump and flowmeter; 5 : hose connection; 6: dome; 7: battery-operated fan; 8: vinyl polychloride base; 9: water flowmeter; 10: $12 \mathrm{~V}$ battery; 11: submersible water pump; 12: multiparameter probe

played on a laptop computer, and successively recorded at $5 \mathrm{~s}$ intervals for $3 \mathrm{~min}$ in the 3 enclosures. This short incubation time limits temperature increases in the enclosures to less than $1.0^{\circ} \mathrm{C}$. NCP during emersion ( $\mathrm{mmol} \mathrm{m}^{-2} \mathrm{~h}^{-1}$ ) was calculated using the equation:

$$
\mathrm{NCP}=\Delta \mathrm{CO}_{2} \times \frac{V}{s \Delta t}
$$

where $\Delta \mathrm{CO}_{2}$ is the change in $\mathrm{CO}_{2}$ concentration during the incubation (ppm), $V$ is the chamber volume (l), $s$ is the enclosed surface area $\left(\mathrm{m}^{2}\right)$ and $\Delta t$ is the incubation time $(\mathrm{h})$.

DIC flux at the sediment-water interface was estimated underwater. In each chamber, the enclosed water was continuously stirred for homogenization using an adjustable submersible pump at $21 \mathrm{~min}^{-1}$, connected to a battery in a waterproof container (Fig. 2B). The dome was removed for at least $20 \mathrm{~min}$ between successive series of measurements to restore ambient conditions. Oxygen, temperature, salinity, and depth were recorded every minute with a multiparameter probe (YSI 6920). The regularity of oxygen concentration ( $\mathrm{mg}^{-1}$ ) as a function of time (min) was used to verify the proper functioning of the system. Seawater samples were collected using $500 \mathrm{ml}$ polyethylene syringes from each chamber at the beginning and end of incubations. pH (total scale, mol kg seawater ${ }^{-1}$ ) was measured within 15 min using a pH meter (Radiometer PH 240) standardized with 2-amino-2-hydroxymethyl-1,3-propanediol hydrochloride and 2-amminopyridine/HCl buffer solutions in synthetic sea water at a salinity of 35 (Dickson et al. 2007) and corrected for temperature and salinity. Samples for total alkalinity (TA) measurements were filtered through Whatman GF/F filters, poisoned with $\mathrm{HgCl}_{2}$, and stored in the dark. To measure TA, Gran titrations were performed on $20 \mathrm{ml}$ subsamples (6 replicates) by the automatic potentiometric method (Radiometer TIM 865) with a $0.01 \mathrm{~mol} \mathrm{l}^{-1} \mathrm{HCl}$ solution (Titrisol, Merck). Phosphate and silicate in ambient water were measured once at each sampling date and concentrations were determined according to Aminot \& Kérouel (2004) using an AutoAnalyser. DIC concentrations $\left(\mathrm{mmol} \mathrm{l}^{-1}\right)$ were calculated from $\mathrm{pH}, \mathrm{TA}$, phosphate and silicate concentrations, temperature, and salinity using the CO2SYS program (Pierrot et al. 2006). NCP during immersion (mmol $\mathrm{m}^{-2} \mathrm{~h}^{-1}$ ) was calculated as the difference between the final and initial concentrations in DIC according to the following equations:

$$
\begin{gathered}
\mathrm{NCP}=\Delta \mathrm{DIC} \times \frac{V}{s \Delta t}-\mathrm{CG} \\
\mathrm{CG}=\Delta \mathrm{TA} \times \frac{V}{2 s \Delta t}
\end{gathered}
$$

where $\triangle \mathrm{DIC}$ is the change in DIC concentration during the incubation $\left(\mathrm{mmol}^{-1}\right), V$ is the chamber volume (l), $s$ is the enclosed surface area $\left(\mathrm{m}^{2}\right), \Delta t$ is the incubation time (h), CG is the estimated net community calcification $\left(\mathrm{mmol} \mathrm{CaCO}_{3} \mathrm{~m}^{-2} \mathrm{~h}^{-1}\right)$, and $\Delta \mathrm{TA}$ is the change in TA $\left(\mathrm{mmol} \mathrm{l}^{-1}\right)$. Both in emersion and in immersion, we assumed that NCP at night or under a dark dome corresponds to $\mathrm{CR}\left(\mathrm{mmol} \mathrm{C} \mathrm{m} \mathrm{C}^{-2} \mathrm{~h}^{-1}\right)$ GCP is the sum of the absolute values of NCP and CR.

\section{Environmental parameters}

Photosynthetically active radiation (PAR, 400$700 \mathrm{~nm}$ ) irradiance in the air ( $\mu \mathrm{mol}$ photons $\mathrm{m}^{-2} \mathrm{~s}^{-1}$ ) and shade air temperature $\left({ }^{\circ} \mathrm{C}\right)$ were recorded every minute from sunrise to sunset, using a quantum sensor (LI-192SA, LI-COR) calibrated for in-air operation and an air temperature sensor (LI-1400-101, LI-COR), 
respectively, connected to a LI-1400 data logger. Underwater PAR ( $\mu \mathrm{mol}$ photons $\mathrm{m}^{-2} \mathrm{~s}^{-1}$ ) was also measured every minute during underwater experiments using the same quantum sensor, calibrated for in-water operation and connected to a LI-1400 data logger in a watertight case. Underwater PAR was measured level to the top of the leaves in seagrass beds and near the sediment in bare sandy bottoms. Sediment subsurface (first centimeter) temperature was recorded every 15 min on a HOBO U12-015 data logger.

In addition, air hygrometry (\%) was recorded near the shore $50 \mathrm{~cm}$ above the ground and $5 \mathrm{~cm}$ above the sediment during low-tide incubations using a hand-held thermo-hygrometer (Luft E200IR). At the end of the experiments, seagrass total living biomass (leaves, rhizomes, and roots) was collected in each enclosure. The plant material was cleaned and dried at $60^{\circ} \mathrm{C}$ for $48 \mathrm{~h}$ in the laboratory to obtain dry weight $\left(\mathrm{g} \mathrm{m}^{-2}\right)$, and the ash-free dry weight (AFDW, $\mathrm{g} \mathrm{m}^{-2}$ ) was calculated after combustion at $450^{\circ} \mathrm{C}$ for $4 \mathrm{~h}$. Sediment was sampled at each station by 3 randomly positioned $2.5 \mathrm{~cm}^{2}$ cores, and kept frozen at $-20^{\circ} \mathrm{C}$ until analysis. Amounts of photosynthetic pigments $\left(\mathrm{mg} \mathrm{m}^{-2}\right)$ were estimated after acetone extraction of the top centimeter for $24 \mathrm{~h}$ at $5^{\circ} \mathrm{C}$. After filtration of the extract, optical densities were measured on a spectrophotometer at $750 \mathrm{~nm}$ and $665 \mathrm{~nm}$. Amounts of chlorophyll a ( $\mathrm{chl} \mathrm{a}$ ) and phaeopigments were calculated as described by Lorenzen (1967). We restricted our analysis to sediment chl $a$ and phaeopigments content because sediment phytopigments have already been the subject of a comprehensive study in the same area by Honkoop et al. (2008). Pigment content of sediment was only assessed in January because a power failure prevented the maintenance of samples frozen in November. Sediment granulometry was determined using a graded series of standard sieves suited to the intervals of the Wentworth (1922) scale. Mean grain size (Folk \& Ward 1957 ) and silt and clay (size fraction $<0.063 \mathrm{~mm}$ ) percentages were calculated.

\section{Data analysis, $P$ vs. $E$ curves}

For each sampling site and period, a MichaelisMenten model (Lederman \& Tett 1981, Vermaat 2009) was iteratively fitted using non-linear regression (Gauss-Newton algorithm) to NCP during submersion and emersion versus in situ PAR irradiance ( $E$, mmol photons $\mathrm{m}^{-2} \mathrm{~h}^{-1}$ ), according to the following equation:

$$
\mathrm{NCP}=\frac{P_{\max } \times E}{K_{\mathrm{m}}+E}-\mathrm{CR}
$$

where $P_{\max }$ is the gross maximal production rate (mmol $\mathrm{C} \mathrm{m}^{-2} \mathrm{~h}^{-1}$ ) and $K_{\mathrm{m}}$ is the half saturation constant (mmol photons $\mathrm{m}^{-2} \mathrm{~h}^{-1}$ ).

\section{Data analysis, daily community metabolism}

Daily community production and respiration rates were determined for each sampling site and period from $P$ vs. $E$ curves established during emersion and immersion. Aerial irradiance was measured every minute over 12 d in November 2008 and 11 d in January 2010. Average underwater irradiance $\left(E_{\mathrm{z}}, \mu \mathrm{mol}\right.$ photons $\mathrm{m}^{-2} \mathrm{~s}^{-1}$ ) was calculated every minute at each subtidal sampling site and during the submersion of intertidal sites according to:

$$
\begin{gathered}
E_{\mathrm{z}}=E_{0} e^{-k_{\mathrm{PAR}} z^{2}} \\
k_{\mathrm{PAR}}=\sum_{i=0}^{\mathrm{n}} \frac{\left(\log E_{z^{*}} \cdot \log E_{0^{*}}\right)}{\mathrm{nz}}
\end{gathered}
$$

where $E_{0}$ is the measured aerial irradiance ( $\mu \mathrm{mol}$ photons $\left.\mathrm{m}^{-2} \mathrm{~s}^{-1}\right), k_{\mathrm{PAR}}$ is the downwelling irradiance attenuation coefficient for the whole PAR waveband $\left(\mathrm{m}^{-1}\right)$ for each site, $\mathrm{z}(\mathrm{m})$ is the depth corrected from tidal effects, $E_{0}$. and $E_{\mathrm{z}}$. ( $\mu \mathrm{mol}$ photons $\left.\mathrm{m}^{-2} \mathrm{~s}^{-1}\right)$ are the recorded aerial and underwater irradiance at depth $\mathrm{z}$, respectively, and $\mathrm{n}$ is the number of simultaneous records of irradiance in the air and underwater.

As no reliable tide table exists for the eastern part of the Banc d'Arguin, a harmonic tidal analysis with nodal corrections was performed for the time series sea-surface height that we established at Iwik from October 5, 2009 to January 8, 2010, using the T_Tide package (Pawlowicz et al. 2002). To be always immersed, a depth gauge (YSI $600 \mathrm{XL}$ ) was placed near the tidal level where the Cymodocea nodosa bed was studied (Gauge 1). From 59 analyzed tidal constituents, 22 constituents were significant at $95 \%$ confidence according to linear analysis. The tide is semidiurnal; the amplitudes of tidal heights are $78 \mathrm{~cm}$ and $24 \mathrm{~cm}$ for the tidal harmonics M2 and S2, respectively, and $8 \mathrm{~cm}$ and $4 \mathrm{~cm}$ for $\mathrm{K} 1$ and $\mathrm{O} 1$, respectively. From this analysis, tidal heights relative to the Gauge 1 level were calculated every minute during the 2 sampling periods. In the absence of an absolute reference depth, we set the working $0 \mathrm{~m}$ tidal level to the Zostera noltii lower distribution limit near Iwik village, where a second identical depth gauge was deployed to calculate the depth differ- 
ence with Gauge 1. Tidal depth relative to this reference was calculated by the model.

$\mathrm{NCP}, \mathrm{GCP}$, and CR were calculated from the input parameters $P_{\max }, K_{\mathrm{m}}, \mathrm{CR}$, and $E$. The error associated with the model corresponded to the standard deviation of the replicate estimates around the mean (Pemberton et al. 2006). E during immersion was calculated with an error associated with $k_{\mathrm{PAR}}$, whereas $E$ recorded during aerial exposure of intertidal stations was taken as exact with no statistical uncertainty. First, average NCP, GCP, and CR values were calculated every minute and a set of 100 randomly generated values of the input parameters, with an assumed normal distribution, was used to estimate their uncertainty by a Monte-Carlo method. NCP, GCP, and CR daily estimates and their 95\% confidence intervals were then calculated by integrating the values over $24 \mathrm{~h}$ and multiplying the errors by 1.96 (Pemberton et al. 2006). As $P$ vs. $E$ relationships were only assessed for 2 seasons, the correlation between $P_{\max }$ and $K_{\mathrm{m}}$ was not considered, leading to an underestimation of errors. Daily average values were calculated for each sampling period (12 d in November 2008 and $11 \mathrm{~d}$ in January 2010). We use the following sign conventions for all carbon exchanges: for NCP, positive values correspond to an uptake of $\mathrm{CO}_{2}$ or DIC by the community; for $\mathrm{CR}$, positive values correspond to a release of $\mathrm{CO}_{2}$ or DIC to the atmosphere or the sea; and for GCP, positive values correspond to an uptake of $\mathrm{CO}_{2}$ or DIC from the atmosphere or the sea.

\section{Statistical analysis}

Mann-Whitney tests were used to compare downwelling irradiance attenuation coefficients $\left(k_{\mathrm{PAR}}\right)$ between seasons and sites, and seagrass biomasses between seasons. Comparison of non-linear model parameters across different data sets was performed using ANOVA, according to Ritz \& Streibig (2008). All data processing was performed using R statistical software (R Development Core Team 2012).

\section{RESULTS}

\section{Environmental and biological characteristics}

Average temperature varied with season but was similar in the air and in sea water, both in November $2008\left(22.5 \pm 4.2^{\circ} \mathrm{C}\right.$ [mean $\pm \mathrm{SD}$ ] in the air and $22.8 \pm$ $0.9^{\circ} \mathrm{C}$ in seawater) and in January $2010\left(19.2 \pm 4.5^{\circ} \mathrm{C}\right.$ in the air and $19.6 \pm 0.3^{\circ} \mathrm{C}$ in seawater). The daily variation in air temperature was $14.1^{\circ} \mathrm{C}$ in November and $17.9^{\circ} \mathrm{C}$ in January. High daily temperature variation was also observed at the surface of emerged intertidal sediment (range $11.2-33.0^{\circ} \mathrm{C}$ in January 2010). The daily temperature of seawater was nearly constant, and variation was much less important in subtidal areas $\left(3.2^{\circ} \mathrm{C}\right.$ in November 2008 and $3.1^{\circ} \mathrm{C}$ in January 2010). $k_{\text {PAR }}$ differed significantly between seasons but not between sites (Mann-Whitney tests). The average $k_{\text {PAR }}$ was higher in November $(0.53 \pm$ $\left.0.12 \mathrm{~m}^{-1}\right)$ than in January $\left(0.39 \pm 0.10 \mathrm{~m}^{-1}\right)$. Average wind speed was $5.9 \mathrm{~m} \mathrm{~s}^{-1}$ in November 2008 and $5.1 \mathrm{~m} \mathrm{~s}^{-1}$ in February 2010.

The mean dissolved oxygen concentration was in equilibrium with the atmosphere, both in November (217 $\mu \mathrm{M}, 99 \%$ air saturation) and in January $(229 \mu \mathrm{M}$, $100 \%$ air saturation). Daily fluctuations were low in channel areas (173-238 $\mu \mathrm{M}$ in November and 201-257 $\mu \mathrm{M}$ in January), but higher in Cymodocea nodosa beds where hypoxia $(60 \mu \mathrm{M}, 28 \%$ air saturation) was observed in November at the end of the night $(04: 15 \mathrm{~h})$ and high oxygen concentrations (357 $\mu \mathrm{M}, 175 \%$ air saturation with bubbles on seagrass leaves) occurred in the afternoon (16:15 h). Variations in oxygen concentration were lower at the same site in January (185-321 $\mu \mathrm{M})$. The absence of significant rainfall combined with high evaporation led to high salinity (average 41.6 in November and 40.3 in January), with daily fluctuations of $\sim 0.8$ during both seasons. The highest salinities were observed at low tide, and the lowest values during high tide. Relative air hygrometry was low both in November $(47.8 \pm 9.6 \%)$ and in January $(34.5 \pm 6.5 \%)$. The daily pattern of irradiance (PAR) was always very regular, with a maximum value at solar noon that was slightly lower in November $(2092 \pm 88 \mu \mathrm{m}$ photons $\left.\mathrm{m}^{-2} \mathrm{~s}^{-1}\right)$ than in January $\left(2296 \pm 125 \mu \mathrm{m}\right.$ photons $\mathrm{m}^{-2}$ $\mathrm{s}^{-1}$ ) due to a higher load of atmospheric dust.

The studied stations differed in depth, sediment granulometry, and pigment (Table 1). The global biomasses of Zostera noltii $\left(223 \pm 26 \mathrm{~g} \mathrm{AFDW} \mathrm{m}^{-2}\right.$ in November, and $212 \pm 30 \mathrm{~g}^{\mathrm{AFDW} \mathrm{m}^{-2}}$ in January) and Cymodocea nodosa $\left(272 \pm 26 \mathrm{~g} \mathrm{AFDW} \mathrm{m}^{-2}\right.$ in November, and $257 \pm 24 \mathrm{~g} \mathrm{AFDW} \mathrm{m}^{-2}$ in January) did not differ significantly between the 2 seasons (MannWhitney test, $\mathrm{p}>0.05$ ) for each seagrass bed, but C. nodosa biomass was always significantly higher than $Z$. noltii biomass (Mann-Whitney test, p < 0.05). Unlike $Z$. noltii leaves, which were barely covered by periphyton, C. nodosa leaves were more damaged and covered with periphyton in January than in November. The AFDW/dry weight biomass ratio was 0.46 for $Z$. noltii and 0.59 for C. nodosa whole shoots. 
Table 1. Characteristics of the sampling sites. Depths are relative to the lower limit of the Zostera noltii beds. Photosynthetic pigment concentration corresponds to the top centimeter of sediments. Chl a values were measured only in January. SD: standard deviation

\begin{tabular}{|c|c|c|c|c|c|c|}
\hline Benthic community & $\begin{array}{l}\text { Depth } \\
\text { (m) }\end{array}$ & $\begin{array}{l}\% \text { silt } \\
\text { and } \\
\text { clay }\end{array}$ & $\begin{array}{c}\text { Mean grain } \\
\text { size }(\mu \mathrm{m}) \\
\text { (sediment type) }\end{array}$ & $\begin{array}{c}\text { Chl a } \\
(\mathrm{SD}) \\
\left(\mathrm{mg} \mathrm{m}^{-2}\right)\end{array}$ & $\begin{array}{l}\text { Phaeopig- } \\
\text { ments (SD) } \\
\left(\mathrm{mg} \mathrm{m}^{-2}\right)\end{array}$ & Chl a \% \\
\hline Zostera noltii bed & +0.9 & 40.8 & 132.6 (fine sand) & $72.3(16.9)$ & $72.9(32.4)$ & 50 \\
\hline Intertidal bare sediment & +0.9 & 17.6 & 169.8 (fine sand) & $28.7(5.8)$ & $18.1(0.7)$ & 61 \\
\hline Cymodocea nodosa bed & -0.7 & 37.6 & 148.6 (fine sand) & $45.7(7.1)$ & $88.8(4.5)$ & 34 \\
\hline Subtidal bare sediment & -2.1 & 12.5 & 311.0 (medium sand) & $47.1(11.6)$ & $56.5(4.9)$ & 45 \\
\hline
\end{tabular}
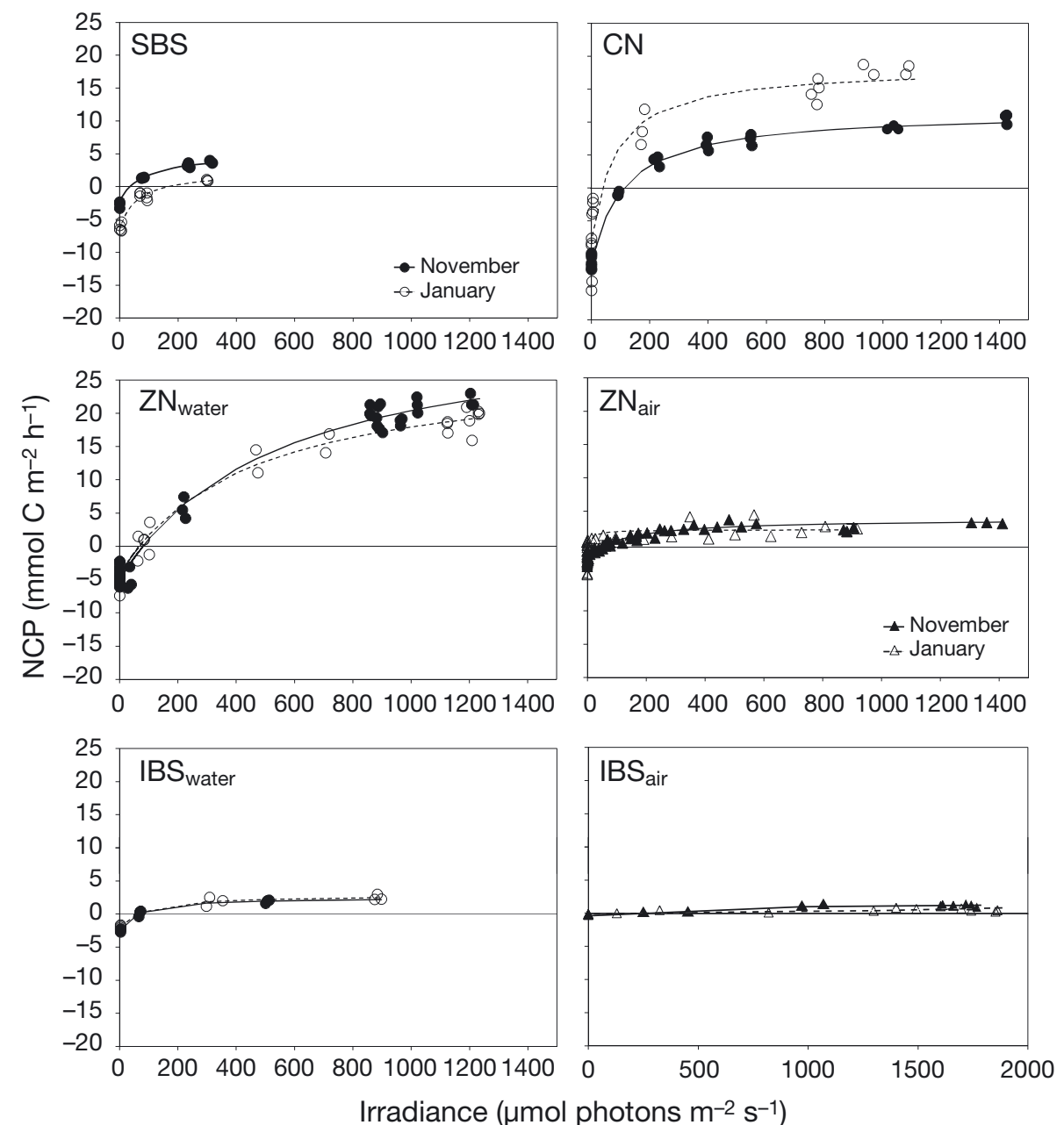

Fig. 3. Relationships between irradiance and net community production (NCP) of a subtidal bare-sediment community (SBS), a Cymodocea nodosa bed $(\mathrm{CN})$, a Zostera noltii bed during submersion $\left(\mathrm{ZN}_{\text {water }}\right)$ and emersion $\left(\mathrm{ZN}_{\text {air }}\right)$, and an intertidal bare-sediment community during submersion ( IBS $_{\text {water }}$ ) and emersion ( IBS $_{\text {air }}$ ), in November 2008 and January 2010

\section{Comparison of $P$ vs. E relationships}

In intertidal areas, $P$ vs. E relationships were always very different during immersion and emersion (Fig. 3), with significantly higher values (ANOVA, $\mathrm{p}<0.01$ ) underwater (Table 2). Only the $P_{\max }$ of the immersed Zostera noltii bed differed significantly between seasons (ANOVA, p < 0.05), with lower values in January, whereas all Michaelis-Menten model parameters differed during emersion (ANOVA, $\mathrm{p}<0.05)$ with lower values in January. $P$ vs. $E$ parameters for the intertidal bare-sediment commu- 
nity were comparatively low and did not vary significantly between seasons (ANOVA, p > 0.05), for both emersion and immersion (Table 2). In subtidal areas, only CR in the bare-sediment community differed significantly between seasons (ANOVA, p < $0.01)$. $P_{\max }$ and $K_{\mathrm{m}}$ were always significantly lower and $\mathrm{CR}$ was significantly higher in the Cymodocea nodosa bed than in the $Z$. noltii bed (ANOVA, $\mathrm{p}<$ 0.01; Table 2).

\section{Variation in daily community metabolism}

At the study site, intertidal and subtidal bare sediment communities were heterotrophic in both seasons (Table 3 ). In addition to the variation with irradiance, we observed a sharp decrease in the NCP of intertidal bare sediments with the time of air exposure at a fairly constant irradiance (Fig. 4). This phenomenon was not observed in the Zostera noltii bed, which was always autotrophic, while the Cymodocea nodosa bed was only autotrophic in January, with an important carbon balance deficit in November. The highest $\mathrm{CR}$ was measured in the subtidal communities, especially the C. nodosa bed. Estimated GCP (Table 3) indicated that, in the studied area, seagrass beds were the major primary producers by surface unit in November (79\% of the total GCP) and in January $(78 \%)$, and that $Z$. noltii beds are likely to export energy to the surrounding areas of the Banc d'Arguin.

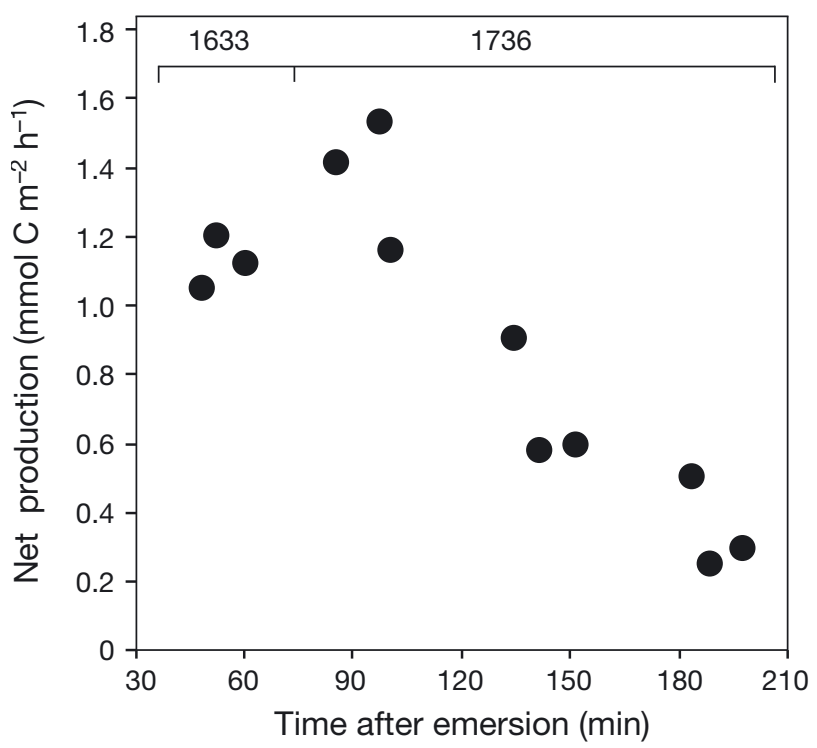

Fig. 4. Effects of desiccation on intertidal bare sediment: temporal evolution of intertidal fine-sand net community production during emersion. Irradiance ( $\mu \mathrm{mol}$ photons $\mathrm{m}^{-2}$ $\mathrm{s}^{-1}$ ) is indicated at the top of the plot

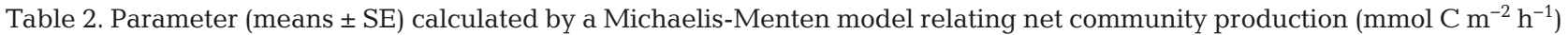
to photosynthetically active radiation irradiance ( $\mu \mathrm{mol}$ photons $\mathrm{m}^{-2} \mathrm{~s}^{-1}$ ) in Novembre 2008 and January $2010 . P_{\max }$ is the gross maximal photosynthetic rate, $K_{\mathrm{m}}$ is the half saturation constant ( $\mu \mathrm{mol}$ photons $\mathrm{m}^{-2} \mathrm{~s}^{-1}$ ), CR is community respiration (mmol C m ${ }^{-2}$ $\mathrm{h}^{-1}$ ), RSE is the residual standard error of the model, and $\mathrm{N}$ is the number of incubations. Parameters that differ significantly

between the 2 seasons (ANOVA) are indicated by ${ }^{*}(p<0.05)$ and ${ }^{* *}(p<0.01)$. See Fig. 3 for community abbreviations

\begin{tabular}{|c|c|c|c|c|c|c|c|c|c|c|}
\hline \multirow{2}{*}{$\begin{array}{l}\text { Benthic } \\
\text { community }\end{array}$} & \multirow[b]{2}{*}{$P_{\max }$} & \multicolumn{2}{|c|}{ November 1-12, 2008} & \multirow[b]{2}{*}{ RSE } & \multirow[b]{2}{*}{$\mathrm{N}$} & \multirow[b]{2}{*}{$P_{\max }$} & \multicolumn{2}{|c|}{ January 21-30, 2010} & \multirow[b]{2}{*}{ RSE } & \multirow[b]{2}{*}{$\mathrm{N}$} \\
\hline & & $K_{\mathrm{m}}$ & $\mathrm{CR}$ & & & & $K_{\mathrm{m}}$ & CR & & \\
\hline $\mathrm{ZN}_{\text {water }}$ & $42.7 \pm 4.2^{*}$ & $681.6 \pm 165.7$ & $5.0 \pm 0.4$ & 1.5 & 36 & $31.8 \pm 2.1^{*}$ & $437.3 \pm 98.8$ & $4.2 \pm 0.6$ & 1.7 & 26 \\
\hline $\mathrm{ZN}_{\text {air }}$ & $5.7 \pm 0.4^{* *}$ & $93.8 \pm 26.0^{*}$ & $2.3 \pm 0.2^{* *}$ & 0.5 & 57 & $3.4 \pm 0.4^{* *}$ & $10.1 \pm 8.8^{*}$ & $1.3 \pm 0.2^{* *}$ & 1.4 & 29 \\
\hline IBS $_{\text {water }}$ & $5.3 \pm 0.4$ & $54.3 \pm 17.0$ & $2.8 \pm 0.3$ & 0.3 & 9 & $5.0 \pm 0.4$ & $82.3 \pm 54.9$ & $2.1 \pm 0.3$ & 0.5 & 9 \\
\hline IBS $_{\text {air }}$ & $1.2 \pm 0.2^{*}$ & $44.7 \pm 159.1$ & $0.2 \pm 0.1$ & 0.1 & 13 & $0.5 \pm 0.2^{*}$ & $35.4 \pm 97.2$ & $0.1 \pm 0.1$ & 0.1 & 13 \\
\hline $\mathrm{CN}$ & $23.0 \pm 1.5$ & $112.3 \pm 30.6$ & $11.4 \pm 1.0$ & 0.8 & 24 & $26.7 \pm 1.5$ & $76.4 \pm 27.7$ & $8.4 \pm 0.8$ & 3.4 & 22 \\
\hline SBS & $7.2 \pm 0.6$ & $53.5 \pm 19.3$ & $2.7 \pm 0.3^{* *}$ & 0.3 & 9 & $9.1 \pm 0.6$ & $58.7 \pm 14.4$ & $6.7 \pm 0.3^{* *}$ & 0.7 & 14 \\
\hline
\end{tabular}

Table 3. Mean $\pm 95 \%$ probability limit for daily carbon net community production ( $\mathrm{NCP}, \mathrm{mmol} \mathrm{C} \mathrm{m} \mathrm{m}^{-2}$ day ${ }^{-1}$ ), gross community production $\left(\mathrm{GCP}, \mathrm{mmol} \mathrm{C} \mathrm{m}{ }^{-2}\right.$ day $\left.^{-1}\right)$, and community respiration $\left(\mathrm{CR}, \mathrm{mmol} \mathrm{C} \mathrm{m}{ }^{-2} \mathrm{day}^{-1}\right)$, determined from measured air and underwater irradiances in November 2008 and January 2010

\begin{tabular}{|c|c|c|c|c|c|c|}
\hline $\begin{array}{l}\text { Benthic } \\
\text { community }\end{array}$ & $\mathrm{NCP}$ & November 1-12, 2008 & CR & \multicolumn{3}{|c|}{ January 21-30, 2010} \\
\hline Zostera noltii bed & $70.8 \pm 65.4$ & $177.8 \pm 55.5$ & $107.0 \pm 16.9$ & $71.7 \pm 51.7$ & $149.6 \pm 38.2$ & $77.9 \pm 22.4$ \\
\hline Intertidal bare sediment & $-13.1 \pm 38.6$ & $41.6 \pm 30.4$ & $54.7 \pm 12.1$ & $-1.5 \pm 54.7$ & $33.2 \pm 47.6$ & $34.7 \pm 11.0$ \\
\hline Cymodocea nodosa bed & $-96.2 \pm 85.1$ & $177.2 \pm 39.5$ & $273.4 \pm 46.2$ & $33.4 \pm 82.6$ & $234.9 \pm 40.9$ & $201.5 \pm 37.4$ \\
\hline Subtidal bare sediment & $-9.3 \pm 35.2$ & $55.5 \pm 23.7$ & $64.8 \pm 14.1$ & $-84.7 \pm 42.5$ & $76.0 \pm 22.6$ & $160.7 \pm 14.1$ \\
\hline
\end{tabular}




\section{DISCUSSION}

\section{Validity of methods for measuring metabolism}

Significant community calcification may occur in seagrass beds (Barrón et al. 2006, Martin et al. 2008, Koch et al. 2013), and we corrected DIC from calcification through TA variation according to the alkalinity anomaly technique (Smith \& Key 1975). We found that, in darkness, this adjustment caused an increase of respiration (DIC production) by $1 \%$ in seagrass beds and by $3.5 \%$ in bare sediment areas (data not shown). Conversely, under saturating irradiance, DIC fluxes were lowered by $11.5 \%$ in seagrass beds and by $42.5 \%$ in bare sediment communities. This high percentage for the bare-sediment areas resulted from metabolic fluxes which were lower than those of seagrass beds. Absolute TA variations were similar in the 4 studied communities, with an associated average carbon flux increase of $0.25( \pm 0.75 \mathrm{SD}) \mathrm{mmol}$ $\mathrm{m}^{-2} \mathrm{~h}^{-1}$ in darkness and an average decrease of 2.13 $( \pm 0.64 \mathrm{SD}) \mathrm{mmol} \mathrm{m}{ }^{-2} \mathrm{~h}^{-1}$ at saturating irradiance. These data would indicate net calcification during the day and carbonate dissolution at night (Bensoussan \& Gattuso 2007). Such calculations assume that TA fluxes at the water-sediment interface are, in addition to production/respiration, only influenced by calcification, but several other biogeochemical processes may change TA in sediment (Barrón et al. 2006, Martin et al. 2007). For instance, ammonia release, net denitrification, and net sulfate reduction can produce alkalinity (Hammond et al. 1999), whereas ammonium removal, reoxidation of reduced sulfur, and nitrification may consume alkalinity (Schindler 1986). High rates of anaerobic biogeochemical processes, especially sulfate reduction, may occur in seagrass beds (Larkum et al. 2006, Holmer 2009), may change the flow of alkalinity, and may prevent a valid measurement of calcification from TA variation alone. These processes were not assessed during our study, and, consequently, our data cannot be used to estimate any potential calcification rate that may have occurred in the seagrass beds. As such, the DIC correction we used must be considered an approximation.

It is commonly assumed that respiration is constant during $24 \mathrm{~h}$ periods, an approximation that can have a significant impact on carbon budgets (Clavier et al. 2008). We measured CR both at night and during the day in opaque enclosures, and our estimates should be close to the daily averages. During our study, seagrass biomasses were similar to those previously reported for the Banc d'Arguin (van Lent et al. 1991,
Vermaat et al. 1993, Honkoop et al. 2008, Folmer et al. 2012), with similar values in November and January.

\section{Comparison of carbon fluxes during immersion and emersion}

One of the main results from this work is that $P$ vs. $E$ curves in the intertidal zone are always very different during emersion and immersion. The few comparisons already published on this subject have provided contradictory results. Alongi et al. (1999) found similar respiration in emersion and submersion in northeastern Australian mud flats and mangrove soils, but CR was higher during submersion in most previous studies (Gribsholt \& Kristensen 2003, Cook et al. 2004, Ouisse et al. 2011, Faber et al. 2012). Results on GCP are also variable. Denis \& Desreumaux (2009) observed only very low production on a temperate immersed mud flat due to water turbidity, and Silva et al. (2005) found a 3-fold higher Zostera noltii bed GCP in emersion compared to immersion along the south coast of Portugal. Conversely, Ouisse et al. (2011) observed a much higher GCP during immersion both for $Z$. noltii and $Z$. marina beds in the western English Channel. They considered that self-shading by seagrass leaves lying on the sediment may explain the low production during low tide (Ouisse et al. 2011), whereas the relative clarity of water in the Banc d'Arguin at the time of our study allows high primary production during immersion. The difference in CR can be ascribed to a deficit in oxygen concentration even if the large variation in temperature may also impact leaf physiology.

We also detected much higher community metabolism during immersion for intertidal bare sediment. Intertidal bare sediment was drained at low tide; the decrease in NCP with the duration of air exposure at constant irradiance in intertidal bare sediment (Fig. 4) indicates that desiccation could also be an important factor controlling metabolism. In the Banc d'Arguin, the microphytobenthos is mainly composed of diatoms (Sterrenburg \& Sterrenburg 1990, De Jong et al. 1991, Honkoop et al. 2008). Intertidal diatoms are known to exhibit tidal-driven vertical migratory behavior with upward migration and the accumulation of cells in a biofilm during light exposure (Guarini et al. 2000, Champenois \& Borges 2012). Such behavior is expected to increase primary production during the day, in contrast to our observations. Similarly, gaseous $\mathrm{CO}_{2}$ emission may be hampered by a reduction in bioturbation during aerial exposure, or by the net accumulation of reduced solutes (Faber et al. 2012). 


\section{Carbon fluxes: spatial and temporal variations}

Daily GCP was high in the Zostera noltii and Cymodocea nodosa beds in this study. However, daily NCP was far lower in the C. nodosa bed due to high $C R$, which exceeded $Z$. zoltii bed respiration by a factor of 2.6 in November and in January. Our estimations of carbon fluxes are similar to those obtained in May 1988 in the same area (De Jong et al. 1991), GCP was estimated at $245 \mathrm{mmol} \mathrm{C} \mathrm{m} \mathrm{m}^{-2}$ for the C. nodosa bed, at $163-353 \mathrm{mmol} \mathrm{C} \mathrm{m} \mathrm{m}^{-2} \mathrm{~d}^{-1}$ for the Z. noltii bed, and $19-41 \mathrm{mmol} \mathrm{C} \mathrm{m}^{-2} \mathrm{~d}^{-1}$ for intertidal bare sediment. With the exception of $C$. nodosa in January, our estimates are slightly lower than the average value calculated from 155 sites (mean $224.9 \mathrm{mmol} \mathrm{C} \mathrm{m}{ }^{-2} \mathrm{~d}^{-1}$ ) considering a metabolic quotient of 1 in the Duarte et al. (2010) analysis. The CR of the $C$. nodosa bed was markedly higher, and that of the $Z$. noltii bed was lower, than the calculated CR average (187.6 mmol $\mathrm{C} \mathrm{m}^{-2} \mathrm{~d}^{-1}$ ). In contrast, the $Z$. noltii bed NCP was higher and the $C$. nodosa NCP was lower, except in January, than the general mean (27.2 mmol $\mathrm{C} \mathrm{m}^{-2} \mathrm{~d}^{-1}$ ), indicating significant excess carbon production. More specifically, our results differ from those reported by Santos et al. (2004), who established a very low NCP for both $Z$. noltii and C. nodosa beds, and a 2-fold higher GCP for a Z. noltii community in Ria Formosa, Portugal. Similarly, a low GCP for a mature C. nodosa bed (20-50 mmol C $\mathrm{m}^{-2} \mathrm{~d}^{-1}$ ) was detected in eastern Spain, leading to net heterotrophy (Barrón et al. 2004). In contrast, a positive NCP (34 mmol C m $\mathrm{m}^{-2}$ ) was calculated for C. nodosa beds in Mallorca (Holmer et al. 2004), and our GCP estimates for C. nodosa meadows are close to those from a coastal lagoon in Corsica (163$288 \mathrm{mmol} \mathrm{C} \mathrm{m}^{-2} \mathrm{~d}^{-1}$ ) reported by Agostini et al. (2003).

The difference in NCP that we observed for the 2 seagrass beds may be related to an accumulation of organic matter in subtidal areas, originating from both autochthonous production and export from intertidal beds that is controlled by hydrodynamics. A similar feature was observed in bare sediments; NCP was very low in intertidal regions, but markedly negative in subtidal areas, for both seasons. The site of the subtidal bare sediments is a channel, where organic matter may accumulate, and our data may correspond to high $\mathrm{CR}$ values. NCP was negligible on intertidal bare sediments, indicating a low potential for organic matter export, but the GCP of the Zostera noltii bed approximately double the NCP for the 2 studied months. We conclude that half of the $Z$. noltii bed production is mineralized in the sur- rounding subtidal areas, or exported to other communities. This export is mostly oriented toward the sea, since the landward transport of leaf material is insignificant in the Banc d'Arguin (Hemminga \& Nieuwenhuize 1991). The GCP of Cymodocea nodosa beds is balanced by $\mathrm{CR}$, leading to a negative NCP in November and a positive NCP in January. This significant winter production may be related to the dense periphyton cover observed in January, when damaged $C$. nodosa leaves were observed, which can compensate for less leaf photosynthesis in the winter (Enríquez et al. 2004). The high CR in the subtidal areas may be due to the mineralization of organic matter produced locally (Holmer et al. 2004) or imported from the intertidal zone, since $Z$. noltii leaf loss is greater than C. nodosa leaf loss in our study area (Vermaat et al. 1993). This leaf loss led to hypoxia at the end of the night in the C. nodosa bed in November and probably during periods when the temperature was relatively high (August-October). An export of $C$. nodosa production corresponding to the amount of allochthonous input is likely to occur in subtidal seagrass beds, although its precise value is difficult to determine.

\section{Contribution to the functioning of the Banc d'Arguin ecosystem}

We found that the vast intertidal seagrass beds were autotrophic in the Banc d'Arguin and were likely to export carbon during the 2 studied seasons. This export may occur through particulate or dissolved organic carbon from seagrass ecosystems (Barrón \& Duarte 2009, Apostolaki et al. 2010). Particulate organic carbon can be carried away by the prevailing winds from the northeast and transported by currents. Many conjectures have been made regarding the circulation of water masses in the Banc d'Arguin and the surrounding areas (Cuq 1993, Dedah 1993, Sevrin-Reyssac 1993, Wolff et al. 1993b, Michel et al. 2009), but because of the complexity of the processes involved and the lack of knowledge about topography, we believe that a comprehensive hydrodynamic and particle transport model is still required to accurately assess the fate of this material. We do know that only a small portion of seagrass primary production directly fuels the local food web (Holmer 2009) after mineralization by bacteria (Michaelis \& Wolff 2001, Honkoop et al. 2008) or is exported to adjacent ecosystems. We observed an accumulation of dead leaves and roots in the sediment. Within the Banc d'Arguin, as in other coastal ecosys- 
tems, seagrass meadows should be considered as a carbon sink with high capacity (blue carbon sink) for the capture and burial of carbon from seawater and the atmosphere (Nellemann et al. 2009). In contrast, microalgal production is an important source of fresh organic matter that can fuel heterotrophic bacteria and benthic invertebrates and play a significant role in the benthic trophic web (Middelburg et al. 2000), especially in seagrass beds (Kaldy et al. 2002). Nutrients from decomposed seagrass detritus are likely to fuel microphytobenthos production, which is often a very important food source for the benthic community of seagrass beds (Lebreton et al. 2009, Lebreton et al. 2012).

NCP was only positive in the Zostera noltii beds during both seasons, with relatively high values. Some organic carbon, mostly rhizomes and roots, may be retained in the sediment over long time scales (Duarte et al. 2010). Our results reveal, however, that $Z$. noltii beds must be regarded as an important source of energy to the surrounding benthic communities of the Banc d'Arguin. Mobile predators such as birds and fishes that depend on the benthic invertebrate food indirectly supported by $Z$. noltii beds are certainly an important pathway for energy export (Wolff et al. 1993a, Michaelis \& Wolff 2001). Our results demonstrate that intertidal and subtidal coastal benthic communities are high production areas likely to export energy to adjacent ecosystems. Preservation of the extensive seagrass beds must, therefore, be a key feature in the conservation strategy of the Banc d'Arguin National Park.

Acknowledgements. This study was funded by the FrancoMauritanian PACOBA project. We thank the Oceanographic and Fisheries Research Mauritanian Institute (IMROP) and the Banc d'Arguin National Park (PNBA) for their support. We also thank L. Lucas for her advice on the manuscript.

\section{LITERATURE CITED}

Agostini S, Pergent G, Marchand B (2003) Growth and primary production of Cymodocea nodosa in a coastal lagoon. Aquat Bot 76:185-193

Alongi DM, Tirendi F, Dixon P, Trott LA, Brunskill GJ (1999) Mineralization of organic matter in intertidal sediments of a tropical semi-enclosed delta. Estuar Coast Shelf Sci 48:451-467

Aminot A, Kérouel R (2004) Hydrologie des écosystèmes marins. Paramètres et analyses. Ifremer editions, Plouzané

Apostolaki ET, Holmer M, Marbà N, Karakassis I (2010) Metabolic imbalance in coastal vegetated (Posidonia oceanica) and unvegetated benthic ecosystems. Ecosystems 13:459-471
Barrón C, Duarte CM (2009) Dissolved organic matter release in a Posidonia oceanica meadow. Mar Ecol Prog Ser 374:75-84

Barrón C, Marba N, Terrados J, Kennedy H, Duarte C (2004) Community metabolism and carbon budget along a gradient of seagrass (Cymodocea nodosa) colonization. Limnol Oceanogr 49:1642-1651

Barrón C, Duarte CM, Frankignoulle M, Borges AV (2006) Organic carbon metabolism and carbonate dynamics in a Mediterranean seagrass (Posidonia oceanica) meadow. Estuaries Coasts 29:417-426

Bensoussan N, Gattuso JP (2007) Community primary production and calcification in a NW Mediterranean ecosystem dominated by calcareous macroalgae. Mar Ecol Prog Ser 334:37-45

Bierman P, Lewis MA, Ostendorf B, Tanner J (2011) A review of methods for analysing spatial and temporal patterns in coastal water quality. Ecol Indic 11:103-114

Champenois W, Borges AV (2012) Seasonal and interannual variations of community metabolism rates of a Posidonia oceanica seagrass meadow. Limnol Oceanogr 57:347-361

Clavier J, Garrigue C (1999) Annual sediment primary production and respiration in a large coral reef lagoon (SW New Caledonia). Mar Ecol Prog Ser 191:79-89

- Clavier J, Chauvaud L, Cuet P, Esbelin C, Frouin P, Taddei D, Thouzeau G (2008) Diel variation of benthic respiration in a coral reef sediment (Reunion Island, Indian Ocean). Estuar Coast Shelf Sci 76:369-377

Clavier J, Chauvaud L, Carlier A, Amice E and others (2011) Aerial and underwater carbon metabolism of a Zostera noltii seagrass bed in the Banc d'Arguin, Mauritania. Aquat Bot 95:24-30

> Cloern JE, Jassby AD (2008) Complex seasonal patterns of primary producers at the land-sea interface. Ecol Lett 11: 1294-1303

Cook PLM, Butler ECV, Eyre BD (2004) Carbon and nitrogen cycling on intertidal mudflats of a temperate Australian estuary. I. Benthic metabolism. Mar Ecol Prog Ser 280:25-38

$>$ Cuq F (1993) Remote sensing of sea surface and coastal features in the area of the Golfe d'Arguin, Mauritania. Hydrobiologia 258:33-40

De Jong SA, Hofman PAG, Sandee AJJ, Nienhuis PH (1991) Community oxygen budgets of seagrass beds and microbial mats on the Banc d'Arguin, Mauritania. In: Herman PMJ, Heip CHR (eds) Proceedings report of the workshop: Modelling the benthos. Delta Institute for Hydrological Research, Yerseke, p 67-68

Dedah S (1993) Wind, surface water temperature, surface salinity and pollution in the area of the Banc d'Arguin, Mauritania. Hydrobiologia 258:9-19

> Denis L, Desreumaux PE (2009) Short-term variability of intertidal microphytobenthic production using an oxygen microprofiling system. Mar Freshw Res 60:712-726

Dickson AG, Sabine CL, Christian JR (2007) Guide to best practices for ocean $\mathrm{CO}_{2}$ measurements. PICES Special Publication 3, IOCCP Report no. 8, Sidney, BC

Duarte CM, Marbà N, Gacia E, Fourqurean JW, Beggins J, Barrón C, Apostolaki ET (2010) Seagrass community metabolism: assessing the carbon sink capacity of seagrass meadows. Global Biogeochem Cycles 24:GB4032, doi:10.1029/2010GB003793

Enríquez S, Marbà N, Cebrián J, Duarte CM (2004) Annual variation in leaf photosynthesis and leaf nutrient content of four Mediterranean seagrasses. Bot Mar 47:295-306 
Faber P, Kessler A, Bull J, McKelvie I, Meysman F, Cook P (2012) The role of alkalinity generation in controlling the fluxes of $\mathrm{CO}_{2}$ during exposure and inundation on tidal flats. Biogeosciences Discuss 9:4087-4097

Folk RL, Ward WC (1957) Brazos River bar: a study in the significance of grain size parameters. J Sediment Res 27: $3-26$

- Folmer EO, van der Geest M, Jansen E, Olff H, Anderson TM, Piersma T, van Gils JA (2012) Seagrass-sediment feedback: an exploration using a non-recursive structural equation model. Ecosystems 15:1380-1393

Geertz-Hansen O, Montes C, Duarte CM, Sand-Jensen K, Marba N, Grillas P (2011) Ecosystem metabolism in a temporary Mediterranean marsh (Doñana National Park, SW Spain). Biogeosciences 8:963-971

Gribsholt B, Kristensen E (2003) Benthic metabolism and sulfur cycling along an inundation gradient in a tidal Spartina anglica salt marsh. Limnol Oceanogr 48:2151-2162

Guarini JM, Blanchard GF, Gros P, Gouleau D, Bacher C (2000) Dynamic model of the short-term variability of microphytobenthic biomass on temperate intertidal mudflats. Mar Ecol Prog Ser 195:291-303

- Hammond DE, Giordani P, Berelson WM, Poletti R (1999) Diagenesis of carbon and nutrients and benthic exchange in sediments of the Northern Adriatic Sea. Mar Chem 66:53-79

> Hemminga MA, Nieuwenhuize J (1991) Transport, deposition and in situ decay of seagrasses in a tropical mudflat area (Banc d'Arguin, Mauritania). Neth J Sea Res 27: 183-190

Holmer M (2009) Productivity and biogeochemical cycling in seagrass ecosystems. In: Perillo GME, Wolanski E, Cahoon DR (eds) Coastal wetlands: an integrated ecosystem approach, Elsevier Science, Amsterdam, p 377-402

Holmer M, Duarte CM, Boschker HTS, Barrón C (2004) Carbon cycling and bacterial carbon sources in pristine and impacted Mediterranean seagrass sediments. Aquat Microb Ecol 36:227-237

Honkoop PJC, Berghuis EM, Holthuijsen S, Lavaleye MSS, Piersma T (2008) Molluscan assemblages of seagrasscovered and bare intertidal flats on the Banc d'Arguin, Mauritania, in relation to characteristics of sediment and organic matter. J Sea Res 60:255-263

Jackson JBC (2008) Ecological extinction and evolution in the brave new ocean. Proc Natl Acad Sci USA 105:11458

> Jager Z (1993) The distribution and abundance of young fish in the Banc d'Arguin, Mauritania. Hydrobiologia 258: 185-196

Jones PJS (2001) Marine protected area strategies: issues, divergences and the search for middle ground. Rev Fish Biol Fish 11:197-216

Kaldy JE, Onuf CP, Eldridge PM, Cifuentes LA (2002) Carbon budget for a subtropical seagrass dominated coastal lagoon: How important are seagrasses to total ecosystem net primary production? Estuaries 25:528-539

> Koch M, Bowes G, Ross C, Zhang XH (2013) Climate change and ocean acidification effects on seagrasses and marine macroalgae. Glob Change Biol 19:103-132

Larkum AWD, Orth RJ, Duarte CM (2006) Seagrasses: biology, ecology, and conservation. Springer, Dordrecht

> Lebreton B, Richard P, Radenac G, Bordes M and others (2009) Are epiphytes a significant component of intertidal Zostera noltii beds? Aquat Bot 91:82-90

> Lebreton B, Richard P, Galois R, Radenac G and others (2012) Food sources used by sediment meiofauna in an intertidal Zostera noltii seagrass bed: a seasonal stable isotope study. Mar Biol 159:1537-1550

Lederman TC, Tett P (1981) Problems in modelling the photosynthesis-light relationship for phytoplankton. Bot Mar 24:125-134

Lorenzen CJ (1967) Determination of chlorophyll and pheopigments: spectrophotometric equations. Limnol Oceanogr 12:343-346

Martin S, Clavier J, Chauvaud L, Thouzeau G (2007) Community metabolism in temperate maerl beds. I. Carbon and carbonate fluxes. Mar Ecol Prog Ser 335:19-29

> Martin S, Rodolfo-Metalpa R, Ransome E, Rowley S, Buia MC, Gattuso JP, Hall-Spencer J (2008) Effects of naturally acidified seawater on seagrass calcareous epibionts. Biol Lett 4:689-692

- Martínez ML, Intralawan A, Vázquez G, Pérez-Maqueo O, Sutton P, Landgrave R (2007) The coasts of our world: ecological, economic and social importance. Ecol Econ 63:254-272

Matias MG, Underwood AJ, Hochuli DF, Coleman RA (2010) Independent effects of patch size and structural complexity on diversity of benthic macroinvertebrates. Ecology 91:1908-1915

Michaelis H, Wolff WJ (2001) Soft-bottom fauna of a tropical (Banc d'Arguin, Mauritania) and a temperate (Juist Area, German North Sea coast) intertidal area. In: Reise K (ed) Ecological comparisons of sedimentary shores. Ecological Studies 151, Springer, Berlin, p 255-274

Michel J, Westphal H, Hanebuth TJJ (2009) Sediment partitioning and winnowing in a mixed eolian-marine system (Mauritanian shelf). Geo-Mar Lett 29:221-232

Michel J, Westphal H, von Cosel R (2011) The mollusk fauna of soft sediments from the tropical, upwelling-influenced shelf of Mauritania (northwestern Africa). Palaios 26: $447-460$

Middelburg JJ, Barranguet C, Henricus TS, Boschker PMJH, Moens T, Heip CHR (2000) The fate of intertidal microphytobenthos carbon: an in situ ${ }^{13} \mathrm{C}$-labeling study. Limnol Oceanogr 45:1224-1234

> Migné A, Davoult D, Spilmont N, Menu D, Boucher G, Gattuso JP, Rybarczyk H (2002) A closed-chamber $\mathrm{CO}_{2}$-flux method for estimating intertidal primary production and respiration under emersed conditions. Mar Biol 140:865-869

Nellemann C, Corcoran E, Duarte CM, Valdes LM, DeYoung C, Fonseca L, Grimsditch G (eds) (2009) Blue carbon: the role of healthy oceans in binding carbon: a rapid response assessment. Earthprint, GRID, Arendal

Ouisse V, Migné A, Davoult D (2011) Community-level carbon flux variability over a tidal cycle in Zostera marina and Z. noltii beds. Mar Ecol Prog Ser 437:79-87

Parker D, Ham J, Woodbury B, Cai L and others (2013) Standardization of flux chamber and wind tunnel flux measurements for quantifying volatile organic compound and ammonia emissions from area sources at animal feeding operations. Atmos Environ 66:72-83

Pawlowicz R, Beardsley B, Lentz S (2002) Classical tidal harmonic analysis including error estimates in MATLAB using T_TIDE. Comput Geosci 28:929-937

> Pemberton KL, Clarke KR, Joint I (2006) Quantifying uncertainties associated with the measurement of primary production. Mar Ecol Prog Ser 322:51-59

Pierrot D, Lewis E, Wallace DWR (2006) MS Excel program developed for $\mathrm{CO}_{2}$ system calculations. ORNL/CDIAC105a. Carbon Dioxide Information Analysis Center, Oak 
Ridge National Laboratory, US Department of Energy, Oak Ridge, TN

R Development Core Team (2012) R: a language and environment for statistical computing. R Foundation for statistical computing, Vienna

Ritz C, Streibig JC (2008) Nonlinear regression with R. Springer, New York, NY

Robinson JG (2011) Ethical pluralism, pragmatism, and sustainability in conservation practice. Biol Conserv 144: 958-965

Santos R, Silva J, Alexandre A, Navarro N, Barrón C, Duarte C (2004) Ecosystem metabolism and carbon fluxes of a tidally-dominated coastal lagoon. Estuaries Coasts 27: 977-985

Schaffmeister BE, Hiddink JG, Wolff WJ (2006) Habitat use of shrimps in the intertidal and shallow subtidal seagrass beds of the tropical Banc d'Arguin, Mauritania. J Sea Res 55:230-243

Schindler DW (1986) The significance of in-lake production of alkalinity. Water Air Soil Pollut 30:931-944

Sevrin-Reyssac J (1993) Hydrology and underwater climate of the Banc d'Arguin, Mauritania: a review. Hydrobiologia 258:1-8

Silva J, Santos R, Calleja ML, Duarte CM (2005) Submerged versus air-exposed intertidal macrophyte productivity: from physiological to community-level assessments. J Exp Mar Biol Ecol 317:87-95

Smith SV, Key GS (1975) Carbon dioxide and metabolism in marine environments. Limnol Oceanogr 20:493-495

Solan M, Cardinale BJ, Downing AL, Engelhardt KAM, Ruesink JL, Srivastava DS (2004) Extinction and ecosystem function in the marine benthos. Science 306: $1177-1180$

Sterrenburg FAS, Sterrenburg FJG (1990) An outline of the marine littoral diatom biocoenosis of the Banc d'Arguin, Mauritania, West Africa. Bot Mar 33:459-465

van Lent F, Nienhuis PH, Verschuure JM (1991) Production and biomass of the seagrasses Zostera noltii Hornem. and Cymodocea nodosa (Ucria) Aschers. at the Banc d'Arguin

Editorial responsibility: Kenneth Heck Jr., Dauphin Island, Alabama, USA
(Mauritania, NW Africa): a preliminary approach. Aquat Bot 41:353-367

- Vermaat JE (2009) Linking clonal growth patterns and ecophysiology allows the prediction of meadow-scale dynamics of seagrass beds. Perspect Plant Ecol Evol Syst11: $137-155$

> Vermaat JE, Beijer JAJ, Gijlstra R, Hootsmans MJM, Philippart CJM, Brink NW, Vierssen W (1993) Leaf dynamics and standing stocks of intertidal Zostera noltii Hornem. and Cymodocea nodosa (Ucria) Ascherson on the Banc d'Arguin (Mauritania). Hydrobiologia 258:59-72

- Viollier E, Rabouille C, Apitz SE, Breuer E and others (2003) Benthic biogeochemistry: state of the art technologies and guidelines for the future of in situ survey. J Exp Mar Biol Ecol 285-286:5-31

Waycott M, Duarte CM, Carruthers TJB, Orth RJ and others (2009) Accelerating loss of seagrasses across the globe threatens coastal ecosystems. Proc Natl Acad Sci USA 106:12377

> Wentworth CK (1922) A scale of grade and class terms for clastic sediments. J Geol 30:377-392

> Wijnsma G, Wolff WJ, Meijboom A, Duiven P, De Vlas J (1999) Species richness and distribution of benthic tidal flat fauna of the Banc d'Arguin, Mauritania. Oceanol Acta 22:233-243

Wolff WJ, Michaelis H (2008) Do shorebirds graze down zoobenthic biomass at the Banc d'Arguin tidal flats in Mauritania? Estuar Coast Shelf Sci 79:491-495

Wolff WJ, Smit CJ (1990) The Banc d'Arguin, Mauritania, as an environment for coastal birds. Ardea 78:17-38

Wolff WJ, Duiven AG, Duiven P, Esselink P and others (1993a) Biomass of macrobenthic tidal flat fauna of the Banc d'Arguin, Mauritania. Hydrobiologia 258:151-163

Wolff WJ, Land J, Nienhuis PH, Wilde P (1993b) The functioning of the ecosystem of the Banc d'Arguin, Mauritania: a review. Hydrobiologia 258:211-222

Worm B, Barbier EB, Beaumont N, Duffy JE and others (2006) Impacts of biodiversity loss on ocean ecosystem services. Science 314:787-790

Submitted: May 6, 2013; Accepted: December 4, 2013 Proofs received from author(s): March 11, 2014 